\title{
Economic valuation of the eco-systemic benefits derived from the environmental asset lake Laguna Santa Elena, through the multi-criteria analysis
}

\author{
C. Romero ${ }^{a}$ (D), P. Arancibia-Avila ${ }^{a *}$, L. Améstica-Rivas $^{b}$, F. Toledo-Montiel ${ }^{a}$ and \\ G. Flores-Morales ${ }^{a}$
}

\begin{abstract}
aDepartamento de Ciencias Básicas, Facultad de Ciencias, Universidad del Bío-Bío, Av. Andrés Bello, 720, Chillán, Chile

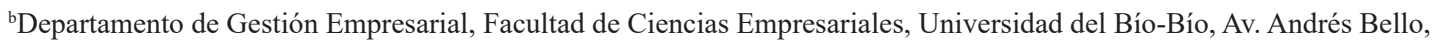
720, Chillán, Chile

*e-mail: parancib@ubiobio.cl
\end{abstract}

Received: November 6, 2018 - Accepted: March 11, 2019 - Distributed: August 31, 2020

(With 1 figure)

\begin{abstract}
Lake Laguna Santa Elena, a freshwater body, located in mid-south of Chile, is an environmental asset used as a water resource by the agricultural and touristic sector and is the habitat for a wide variety of endemic avifauna. The objective of this study was to assign a monetary value to this lacustrine body, using the methodology of AMUVAM (Multicriteria Analysis of Environmental Active Values). The information was collected through the application of surveys to a panel of experts involved in the use of the environmental resource. The result obtained with the AMUVAM method corresponds to the US \$17,780,686, a figure that represents an estimated value of the TEV (Total Economic Value) of the environmental asset. This study, a pioneer in the Region, will support decision making, allowing an adequate management of this critical water resource.
\end{abstract}

Keywords: AMUVAM methodology, management of natural resources, water resource.

\section{Valoração econômica dos benefícios ecossistêmicos derivados do ativo ambiental Laguna Santa Elena por meio da análise multicritério}

\section{Resumo}

A Laguna Santa Elena, um corpo de água doce localizado no centro-sul do Chile, é um ativo ambiental usado como recurso hídrico pelos setores agrícola e turístico e é o habitat de uma ampla variedade de avifauna endêmica. O objetivo deste estudo foi atribuir um valor monetário a esse corpo lacustre, utilizando a metodologia da AMUVAM (Análise Multicritério de Valores Ambientais Ativos). As informações foram coletadas por meio da aplicação de pesquisas a um painel de especialistas envolvidos no uso do recurso ambiental. O resultado obtido com o método AMUVAM corresponde a US\$ 17.780.686, que representam um valor estimado do valor econômico total (VT) do ativo ambiental. Este estudo, pioneiro na região, apoiará a tomada de decisões, permitindo um gerenciamento adequado desse recurso hídrico crítico.

Palavras-chave: metodologia AMUVAM, manejo de recursos naturais, recurso hídrico.

\section{Introduction}

The dynamics of the Chilean economy is based on the export of renewable natural resources such as fruits, cellulose, salmon, and mineral resources. The previous has caused regional impacts, such as the change in land use due to the pressure exerted in the felling of forests and private appropriations of our natural resources. It has also caused socio-environmental impacts due to the diversion of the destination of capital to global markets (Rehner et al., 2014)

The collateral effects of economic projects or activities are known as negative externalities studied by the environmental economy. The negative externalities occur when the market behavior or an agent of this, transfer to others the effects or costs produced without rewards. In other words, the welfare of society is affected by the activity of a particular person. The environmental economy, a branch of the economic sciences, studies the optimal value allocation to exhaustible resources for the intergenerational equity, has emerged (Riera et al., 2016). Concretely, it consists in giving a monetary value to environmental goods and services, which are not traded in the markets and therefore do not have an explicit price; this tool is better known as the economic valuation of an environmental asset (Lee et al., 2010). 
The objective of economic valuation is to provide information to the people who make decisions, favoring the better management of natural resources (Aznar-Bellver and Estruch-Guitart, 2015), as well as contribute and progress in the management plans of environmental services (Berroterán and González Marcano, 2010).

The second report of environmental performance evaluations elaborated by the OECD in 2016, indicates that unlike most of the member countries of the OECD, Chile does not apply penal sanctions for environmental crimes (CEPAL and OCDE, 2016; OECD, 2016). Taking into consideration the above, the option of valuing ecological assets could become a solution to prevent environmental damage.

Economic valuation of environmental assets surges as an instrument for the management of natural resources, and should not be used as a value for subsequent commercialization. Aquatic resources are scarce and often deteriorating due to the high demand from industries, agriculture, public domain users, among others (FAO, 2017). The aquatic resource lake Laguna Santa Elena is located on the border of exotic forest plantations (Pinus radiata (D. Don, 1836), Eucalyptus globulus (J. Labillardière, 1800) and large areas of traditional agriculture, providing ecosystem services that have not been valued to date.

This aquatic resource is subject to environmental impacts of different levels, i.e. cattle and agriculture activities, hunting, egg collection, water pollution, and recently exotic species invasions such as a freshwater jellyfish, Craspedacusta sowerbii (Lankester, 1880) (Fraire-Pacheco et al., 2017).

In 2002, the former National Environmental Commission (Ministerio del Medio Ambiente (Chile, 2016)) declared lake Laguna Santa Elena a priority site for conservation in the Regional Strategy and Action Plan for Biodiversity. The location is appropriate for the observation of 44 species of birds of which the common snipe Gallinago gallinago (Linnaeus, 1758) and the black-necked swan (Cygnus melancoryphus (Molina, 1782) depend on water level for reproduction and food availability (González-Acuña et al., 2004).

Freshwater as a global natural resource it is also declared a human right and it is a fundamental element of the political issue for the development and survival of societies, anticipating potential contamination, and the effects of the physical-natural factors that might affect it (Obando-Bastidas et al., 2016).

Undoubtedly, the contamination of water by pollutant sources causes the progressive deterioration of their value. Several reasons might support the idea to approximate the economic value of natural resources. One of them is that this information serves as a basis in the political decisions of conservation and protection, and also to know the value of the natural heritage for those who defend it.

Assessing economic value to environmental goods and services from a defined market perspective is complex. The reason for its complexity is based on the benefit-cost relation of these environmental assets as such or when an environmental problem is established. It becomes even more complex especially from a public policy perspective that seeks to sanction those who cause damage to the natural heritage of a country, finding the sustainable use of the environment and natural resources in the future (Bateman, 2011).

Economic valuation approaches on environmental issues are carried out based on cost-benefit or cost-effectiveness criteria (Henri and Journeault, 2010; Jones et al., 2018). The latter referred to an environmental quality goal or goal expressed in equivalent terms for a given resource expenditure. Different methods have been used, such as contingent valuation, a technique widely used in the assessment of environmental quality regarding its conservation of biological diversity (Carson, 2012) and its tourist potential (Adams et al., 2008). In this method, experts are consulted in certain contingencies of what they are willing to pay or willing to accept to pay. In Latin America, the contingent valuation method for protected natural areas is exhaustively used (Resende et al., 2017).

The travel cost method has been used to estimate the value of recreational use (Hausman, 2012). However, several retractors of that form of valorization have emerged (Hidalgo-Fernández and Hidalgo Fernández, 2016). The variability in the ways of economic valuation carried out and the delimitation of the ecosystems add complexity to the aggregation of the results of different investigations in financial cost (De la Barrera et al., 2015). The values of use in this type of studies prevail over the benefits of non-use. The methods that stand out correspond to contingent valuation, market prices, travel cost, among others. Therefore, it is necessary to include holistic methodologies that incorporate the goods and services that environmental assets provide and not only accounting for the monetary aspects they generate. For that reason, in this study, we decided to work with a multi-criteria method, which incorporates all the components of values of use and non-use, present in the environmental asset.

This methodology makes it possible to show that environmental assets can be granted an economic value, not as a commercial asset, but rather to clarify the amount they represent for the services provided, whether to the public or private sector. It is also a tool that is used to gather the highest number of criteria present in the area to be studied, generating a real assessment (Jones et al., 2018)

Although lake Laguna Santa Elena is declared a priority site for conservation, it lacks a regulatory framework mainly because the property regime is associated with the private sector. The information on the eco-systemic benefits derived from the environmental asset, lake Laguna Santa Elena, will make it possible to value it economically by asking the user preferences to members of the surrounding community with enough knowledge of the environmental asset. 


\section{Material and Methods}

\subsection{Description of the study area}

Lake Laguna Santa Elena is located $40 \mathrm{Km}$ south from the nearest city Chillán, in mid-south Chile (Figure 1). It is a shallow lake ( $\mathrm{Z}$ max: $14 \mathrm{~m}$ ), with an area of 59 ha and a perimeter of 5,132.92 m. (Fraire-Pacheco et al., 2017). The prevailing climate is Mediterranean and average annual temperature ranges from $13.5^{\circ} \mathrm{C}$ to $14.0^{\circ} \mathrm{C}$. The lake watershed is influenced by agricultural and forestry activities (González-Acuña et al., 2004) and local tourism (Fraire-Pacheco et al. 2017). The freshwater body has emergent and submerged aquatic vegetation surrounding the whole litoral perimeter (Fraire-Pacheco et al., 2017) and is home to more than 45 avifauna species, several endemic (González-Acuña et al., 2004), and migratory birds (Jaramillo et al. 2005).

\subsection{Multi-Criteria Method (MCM)}

The opinion of a panel of experts was used in the multi-criteria method of the Analytic Hierarchy Process (AHP) (Saaty, 2008). The panel of experts evaluates alternatives through the comparison of pairs, in a selection of other options based on a series of criteria or variables, which are often in conflict. This approach allows each expert to elaborate a matrix of hierarchies of their alternatives with a more significant influence on the problem seen as a whole (Aznar-Bellver and Guijarro-Martínez, 2012).

Twelve knowledgeable experts having a link to the environmental asset Lake Laguna Santa Elena answered the surveys. The experts were chosen from different areas, to reduce biased decisions based on emotional or particular interests (Noble, 2004). The panel of selected experts had the status of residents, municipal representatives, and members of the neighborhood board, biologists, and engineers, among others (Table 1).

State of the art regarding the most suitable number of experts ranges from 10 to 18 experts (Bennour and Crestani, 2010). Another approach is not to establish a specific number of experts but instead reflect the quality of the specialists as their years of experience in the subject (Gordon and Dahl, 2013).

\subsection{Study variables}

The AHP methodology is a multi-criteria type tool that allows experts to give weight to the evaluation criteria or alternatives through a systematic comparison by pairs of each of the options in evaluation (Liu et al., 2011). Under the above, the variables to be compared by the experts in this study are based on the methodology used by Aznar-Bellver and Guijarro-Martínez (2012) for the case of environmental assets that seeks to find the Total Economic Value (TEV) through its various components.

The benefits are expressed under the concept of total economic value (TEV) of any resource, including water, which is given by the Use Value (UV). Although individuals do not use a resource, it is possible that is valuable to them, thus introducing the concept of Non-Use Value (NUV). The Use Value can be divided into Direct Use Value (DUV), Indirect Use Value (IUV) and Option Value (OV). On the other hand, the Non-Use Value (NUV) categories are the Value of Existence (VE) and the Bequest Value (BV) (Table 2).

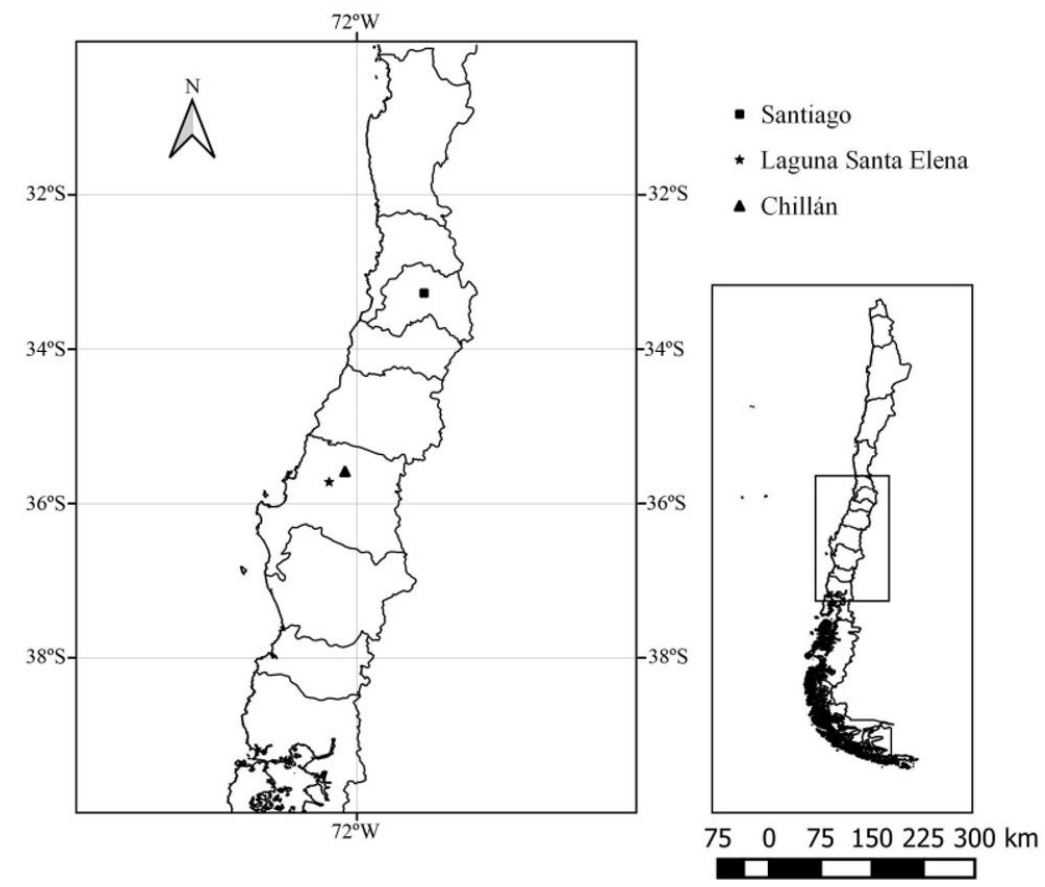

Figure 1. Map of Chile showing location of the lake Laguna Santa Elena $40 \mathrm{~km}$ south of Chillán, the nearest city. 
Table 1. The panel of experts interviewed showing the actual relationship with the environmental asset Lake Laguna Santa Elena.

\begin{tabular}{llc}
\hline \multicolumn{1}{c}{ Relationship with the asset } & \multicolumn{1}{c}{ Origin } & Number of experts \\
\hline Tourism Department & Municipality of Bulnes & 2 \\
Biologist, Limnologist, Engineer Researchers & Regional University & 4 \\
Tourism, Agriculture entrepreneurs & Neighboring community & 2 \\
President of Community of Neighbors and residents & Neighboring community & 4 \\
Total Number of experts & & $\mathbf{1 2}$ \\
\hline
\end{tabular}

Table 2. Identification and description of the Total Economic Values (TEV) components.

\begin{tabular}{|c|c|c|}
\hline Abbreviations & Criteria Values & Description \\
\hline DUV & Direct Use Value & $\begin{array}{l}\text { Represents benefits produced by natural assets either as materials for } \\
\text { production processes or as goods. }\end{array}$ \\
\hline IUV & Indirect Use Value & $\begin{array}{l}\text { Goods and services that are necessary to obtain the value of the direct } \\
\text { use and are not detected by the market. }\end{array}$ \\
\hline $\mathrm{OV}$ & Option/quasi-option & $\begin{array}{l}\text { Asset value with unknown functions, or possible future uses of the } \\
\text { property. }\end{array}$ \\
\hline EV & Existence Value & $\begin{array}{l}\text { Value of the asset by allowing biodiversity or conservation of the } \\
\text { resource. }\end{array}$ \\
\hline BV & Bequest Value & The value of the asset for future generations or inheritance. \\
\hline TEV & Total Economic Value & $\mathrm{DUV}+\mathrm{IUV}+\mathrm{OV}+\mathrm{EV}+\mathrm{BV}$ \\
\hline
\end{tabular}

Source: Modified from Aznar-Bellver and Guijarro-Martínez (2012).

Based on the information collected, matrices were constructed from which the eigenvector was deduced, added to the weighting of the TEV components. The criteria were prioritized by the experts when they were surveyed, using two paired questions for each pair of standards. Since there is no certainty that the decisions made by the experts are the most optimal due to natural biases and the possibility of inconsistency in their judgments, the AHP method applies two measures: the consistency index (CI) and the consistency ratio (CR), following equations based on Aznar-Bellver and Estruch-Guitart (2015) (Equations 1, 2, 3).

$$
C I=\frac{C A-n}{n-1}
$$

Where: CA: consistency average; $\mathrm{n}$ : number of criteria.

The CA value is obtained using the methodology of Toledo et al. (2011). The matrix generated with each expert opinion values was normalized and the eigenvector calculated as an arithmetic average for each row (Toledo et al., 2011). The final eigenvector values per row were then added to obtain the CA, also called $\lambda_{(\max )}$ (Toledo et al., 2011). The number of criteria in this case was five.

The random consistency index (RCI) is given by:

$R C I=\frac{1,98 *(n-2)}{n}$

So, the consistency ratio (CR) is given by:

$C R=\frac{C I}{R C I}$
The measures described above allow us to establish to what extent the decision in the comparison by pairs is consistent and is not influenced by contradictions or biases (Alonso et al., 2008).

The paired comparison matrices and the different eigenvectors obtained do not have to be the same, and they can differ from each other. We needed to get a unique eigenvector, a product of the aggregation of all eigenvectors. For this, it was necessary to calculate the geometric mean of all of them. Once the aggregate of eigenvectors was obtained, it was normalized by addition, and this step was carried out with the purpose of having a single prioritization of the experts, with an acceptable ratio of consistency less than $10 \%$. Survey limitations that might affect the ratio of consistency are related to the expert's time available to respond to the survey, the expert's interest and its knowledge about the terminology used in the survey. Representing in this way the final weight of the respondents and showing the value of each of the variables of the TEV.

\subsection{Revenue update method}

This method was used because it values goods originating income and expenses, in a specific time. In this case, the value of an economic asset is equal to the current value of the sum of future income (profits, cash flows) that the good generates for its owner, based on a principle of anticipation. We considered the income obtained as a result of an economic activity that would benefit from the environmental asset, in addition to finding an interest rate. In the case of environmental or public projects, such as lake Laguna Santa Elena, an interest rate is established, equal to the social discount rate, to maximize the welfare 
of society and future generations because the discount rates of the market, seek to maximize private protection (Aznar-Bellver and Estruch-Guitart, 2015).

The following formula explains how the rents (FC) were updated considering perpetuity with growth $(\mathrm{g})$ at a social discount rate (r) (Equation 4).

$V=\sum_{t=1}^{n} \frac{F C t}{(1+r)^{t}} \approx \frac{F C}{r-g}$

Where: V: Value of the environmental asset, by the functions performed by the value of a direct use; FC: Revenues obtained from ecological assets, due to the services performed by the amount of a direct use; r: Social discount rate; g: Rate of growth of future flows; $t$ : Number of periods

\subsection{AMUVAM method}

The AMUVAM method (Analytic Multicriteria Valuation Method), applied to make the valuation of the environmental asset lake Laguna Santa Elena, combines the AHP, and the income update method (Aznar-Bellver and Guijarro-Martínez, 2012). It delimits the details of the total economic value (TEV) that exist in the asset, in such a way to weight the components of the same through the AHP. Once weighted, the DUV is used as the pivot value (this value includes the activities of the environmental asset that are controlled by the market). With the existence of the market, we may know the income and expenses that produce the functions that comprise the DUV; the difference between the two corresponds to the cash flow $(\mathrm{CF})$.

Subsequently, through the use of the environmental rate or social discount rate, which is equal to $6 \%$ in Chile (Edwards, 2016) and applying the rent update, the cash flows and the value obtained was updated, which turned out to be the value of the environmental asset (Equation 5).

$$
D U V=\frac{C F}{\text { ӥйӥйӥй̈̈ }}
$$

The values of the TEV elements were calculated only when the DUV of the asset and the weights of the value of the TEV were known. When adding all these values, the TEV of the environmental asset was obtained. Whenever, DUVs could not be determined, the IUV was used as a pivot value.

\section{Results}

The experts' prioritizations with an acceptable ratio of consistency less than $10 \%$ were numbered 1, 2, 4, 7, 8, 9,10 and 11 , for a matrix of size $n=5 \times 5$.

The use of AHP generates an indicator for the quality of responses given; three of the surveys $(25 \%)$ were found to be inconsistent, and therefore discarded. Despite the above, $75 \%$ of consistent answers were sufficient to determine the TEV of lake Laguna Santa Elena.

Next step included the aggregation of the eigenvectors (each expert has different prioritization for the elements of the TEV) using the function of Geometric Media, to later normalize them, through addition. For this, each added value was divided by the result of the sum of all the values that were added, in this case, 0.92434 (Table 3).

The eigenvector indicated the prioritization of the experts concerning the elements of the TEV. The ordered list of values according to its magnitude was: IUV with $36.39 \%$; EV with $26.72 \%$; BV with $26.64 \%$; OV with $6.17 \%$; DUV with $4.06 \%$ (Table 3 ).

Consecutively to the above, cash flow was made from the income or profits that occur in the vicinity of the environmental asset lake Laguna Santa Elena, which are directly derived from the economic activities identified in the field and which give rise to the DUV. We observed two business activity areas that are benefited by the presence of the lake body. They correspond to a micro business tourism activity that operates in summer and another of agriculture corresponding to a local entrepreneur who cultivates 50 hectares. Both actors provided their financial information and economy returns through an unstructured interview. The delivered information was systematized (Table 4).

The economic activities developed in the territory are relevant to calculate the economic value of a particular place and will determine our final result. Due to the annual variability of the income, an average of the costs and profits recorded in the different items during the last years was done. Therefore, the total return obtained from the presence of direct economic activities linked to the lake was US\$ 28,935.62 per year. The environmental rate or social discount rate (equal to $6 \%$ ) estimated for Chile by the Ministry of Social Development was used to calculate the current value of economic rent (Edwards, 2016). Likewise, a growth rate " $g$ " of future flows of $2 \%$ was assessed, taking as a reference an average growth of the national product (GDP) of the last years, obtaining perpetuity with the increase.

Finally, given the pivot value of the valuation (US $\$ 28,935.62 /(6 \%-2 \%))$ the end result of the DUV was US\$ 723,140 . In this way, the other components of the TEV model were estimated, reaching a total value of US \$17,780,686 (Table 5).

Table 3. Aggregated weights of the eigenvectors using the function of Geometric Mean, to later normalize them, through addition.

\begin{tabular}{ccc}
\hline Criteria & $\begin{array}{c}\text { Geometric } \\
\text { Mean }\end{array}$ & Normalized \\
\hline DUV & 0.03759 & 0.04067 \\
IUV & 0.33642 & 0.36395 \\
OV & 0.05703 & 0.06170 \\
EV & 0.24703 & 0.26726 \\
BV & 0.24626 & 0.26642 \\
TEV & $\mathbf{0 . 9 2 4 3 4}$ & $\mathbf{1 . 0 0 0 0 0}$ \\
\hline
\end{tabular}


Table 4. Annual cash flow from the income or profits that occur in the vicinity of the environmental asset Lake Laguna Santa Elena, which are directly derived from the economic activities identified in the field.

\begin{tabular}{lccc}
\hline \multicolumn{1}{c}{ Activity } & Incomes (US\$) & Operational Costs (US\$) & Margin (US\$) \\
\hline Agriculture & $37,190.08$ & $9,917.36$ & $27,272.73$ \\
Tourism & $4,132.23$ & $2,469.34$ & $1,662.89$ \\
Total Annual Cash Flow & & & $\mathbf{2 8 , 9 3 5 . 6 2}$ \\
\hline
\end{tabular}

Table 5. Final Valuation in US\$, for TEV (Total Economic Value) components and the final TEV, of the environmental asset lake Laguna Santa Elena.

\begin{tabular}{ccc}
\hline Criteria & Prioritization & $\begin{array}{c}\text { Valoration } \\
\text { (US\$) }\end{array}$ \\
\hline DUV & 0.04067 & 723,140 \\
IUV & 0.36395 & $6,471,281$ \\
OV & 0.06170 & $1,097,068$ \\
EV & 0.26726 & $4,752,066$ \\
BV & 0.26642 & $4,737,130$ \\
TEV & $\mathbf{1 . 0 0 0 0 0}$ & $\mathbf{1 7 , 7 8 0 , 6 8 6}$ \\
\hline
\end{tabular}

\section{Discussion}

Lake Laguna Santa Elena is the first environmental assessment study carried out in the Region. The study showed the importance given to each of the variables by the panel of experts consulted, considering the IUV as the most relevant component of valuation with $36.39 \%$ of the score, followed by the EV with $26.72 \%$ and BV with $26.64 \%$. These three factors added up to $89.51 \%$ of the total weighting of the instrument, leaving the DUV (market) as $4.07 \%$ and the OV at $6.17 \%$, respectively. The estimated total economic value (TEV) gives an approximation of the value of the lake of US $\$ 17,780,686$ showing that the eco-systemic benefits obtained from the environmental asset are essential to the neighboring community.

For this type of methodology, a social discount rate generated by the country must be always considered (Edwards, 2016), which have an impact in the final result. A high social discount rate means that society finds it more important to favor the value of use in the present, than to prioritize the use value of our resources in the future. Therefore, the conservation and use of natural resources deteriorate over time, affecting future generations (Correa-Restrepo, 2008). Countries should tend to minimize the social discount rates to better valuate environmental assets. However, the fact that discount rates vary over time can generate changes in environmental project decisions (Arrow et al., 2014).

Although the acquired TEV does not represent the real value of the environmental asset, it constitutes an indicator that can contribute to the welfare and sustainability of society (Jones et al., 2018). In parallel, the index would add relevant information for a future Strategic Environmental Assessment. In other words, facilitate to be ahead of possible environmental and sustainability consequences, where the opportunities that exist in a territory can be used to the maximum, avoiding potential conflict situations. Simultaneously this information can support an Environmental Impact Assessment, either in the preparation of the baseline or in mitigating environmental and social impacts. Favoring the concept of sustainable development, conservation of the environment, and contributing to the strengthening of decision processes, as a predictable way of territorial planning (Chile, 2012).

The Environmental Assessment Service created in Chile ensures that any project or activity likely to cause environmental impact, in any of its phases, must be submitted to the Environmental Impact Assessment System. It applies or works against environmental liabilities, or ecological damage (regarding water pollution, soil, air, deterioration of resources and ecosystems) generated by the projects of a company, during its operation or past ecological accidents but does not work preventively with environmental assets. That is why, by virtue of the aforementioned, the TEV of the ecological asset can be used as a prevention mechanism, to avoid costly errors in the future or even as a tool that allows the environmental tribunals or the competent entities to take the best-informed decisions, generate compensations for the damage caused to the stability of the ecosystem (Toledo et al., 2011).

Besides, an environmental asset may provide cultural services to society that can be inherited to future generations thus representing a development opportunity for the eco-tourism sector. Those mentioned above can favor the relationship of a sustainable use with the economic activities that take place in the area, social welfare and environmental balance (Maldonado, 2015).

The environmental asset lake Laguna Santa Elena, like all aquatic resources, plays a relevant role in the ecosystem. Among others, it contributes to the stabilization of the climate, flood control; it is a permanent source of water in case of forest fires, it is also a refuge and a nesting site for birds, some of them in a vulnerable state of conservation. Given that, it is considered a priority site for conservation (Fraire-Pacheco et al., 2017; González-Acuña et al., 2004).

The fact of granting a quantitative sum, adjusted to the reality, not only helps in decision making, but also allows the generation of an indicator of great importance for environmental management. It gives information, which can be used to elaborate on or modify existing policies (Rahman et al., 2018) and may also be used to make a wise decision about approving or not a specific business project, thus avoiding the costs outsourced to society. Therefore, the new plans created, which include valuation of the environmental asset, will be satisfactory and adequate for sustainable production. This study, pioneer in Chile, will enable the governmental authorities to make informed decisions on long-term ecological 
projects. The AMUVAM method, chosen to evaluate the environmental asset, is a good indicator for a future Strategic Environmental Assessment.

\section{Conclusion}

Lake Laguna Santa Elena is highly valued by the surrounding community who recognize to have in return an environmental asset with a high eco-systemic value. The AMUVAM method managed to collect a total economic cost for lake Laguna Santa Elena of US\$17,780,686 by applying a social discount of $6 \%$, meaning that the eco-systemic benefits obtained from the environmental asset are essential to the neighboring community. The environmental asset under study might maintain a future eco-systemic value similar to the current one.

\section{Acknowledgements}

The authors wish to thanks the University of Bio-Bio for its support. Help provided by the research assistant Rodolfo Caro was highly valuable.

\section{References}

ADAMS, C., MOTTA, R.S., ORTIZ, R.A., REID, J., AZNAR, C.E. and SINISGALLI, P.A.D., 2008. The use of contingent valuation for evaluating protected areas in the developing world: Economic valuation of Morro do Diabo State Park, Atlantic Rainforest, São Paulo State (Brazil). Ecological Economics, vol. 66, no. 2-3, pp. 359-370. http://dx.doi.org/10.1016/j.ecolecon.2007.09.008.

ALONSO, S., CHICLANA, F., HERRERA, F., HERRERAVIEDMA, E., ALCALÁ-FDEZ, J. and PORCEL, C., 2008. A consistency-based procedure to estimate missing pairwise preference values. International Journal of Intelligent Systems, vol. 23, no. 2, pp. 155-175. http://dx.doi.org/10.1002/int.20262.

ARROW, K.J., CROPPER, M.L., GOLLIER, C., GROOM, B., HEAL, G.M., NEWELL, R.G., NORDHAUS, W.D., PINDYCK, R.S., PIZER, W.A., PORTNEY, P.R., STERNER, T., TOL, R.S.J. and WEITZMAN, M.L., 2014. Should governments use a declining discount rate in project analysis? Review of Environmental Economics and Policy, vol. 8, no. 2, pp. 145-163. http://dx.doi. org/10.1093/reep/reu008.

AZNAR-BELLVER, J. and ESTRUCH-GUITART, A.V., 2015. Valoración de activos ambientales: teoría y casos. 2. ed. Valencia: Ed. Universitat Politécnica de Valéncia, 241 pp.

AZNAR-BELLVER, J. and GUIJARRO-MARTÍNEZ, F., 2012. Nuevos métodos de valoración: modelos multicriterio. 2. ed. Valencia: Ed. Universitat Politècnica de València, 278 pp.

BATEMAN, I.J., 2011. Valid value estimates and value estimate validation: better methods and better testing for stated preference research. In: J. BENNETT, ed. The international handbook on non-marketed environmental valuation. New York: Edward Elgar Publishers, pp. 322-352. http://dx.doi.org/10.4337/9780 857931191.00021 .

BENNOUR, M. and CRESTANI, D., 2010. Formalization of process activity performance estimation approach using human competencies. International Journal of Production Research, vol. 45, no. 24, pp. 5743-5768. http://dx.doi.org/10.1080/00207540600654459.
BERROTERÁN, M.A. and GONZÁLEZ MARCANO, Y., 2010. Valoración economica del paisaje para la gestión sostenible del area de playa puerto viejo, Municipio Gomez, Estado Nueva Esparta. Venezuela. Gestión Turística, vol. 13, no. 13, pp. 63-91. http://dx.doi.org/10.4206/gest.tur.2010.n13-03.

CARSON, R.T., 2012. Contingent valuation: a practical alternative when prices aren't available. The Journal of Economic Perspectives, vol. 26, no. 4, pp. 27-42. http://dx.doi.org/10.1257/jep.26.4.27.

CHILE. Ministerio del Medio Ambiente, 2012 [viewed 27 August 2018]. Aprueba reglamento del sistema de evaluación de impacto ambiental [online]. Available from: http://www.leychile. $\mathrm{cl} / \mathrm{N} ? \mathrm{i}=1053563 \& \mathrm{f}=2014-10-06 \& \mathrm{p}=$

CHILE. Ministerio del Medio Ambiente, 2016. Diagnóstico estado y tendencias de la biodiversidad: región del Bío Bío. Chile: División de Recursos Naturales y Biodiversidad, Departamento de Políticas y Planificación de la Biodiversidad, Ministerio del Medio Ambiente.

COMISIÓN ECONÓMICA PARA AMÉRICA LATINA Y EL CARIBE - CEPAL and ORGANIZACIÓN PARA LA COOPERACIÓN Y EL DESARROLLO ECONÓMICOS - OCDE, 2016 [viewed 27 August 2018]. Evaluaciones del desempeño ambiental de Chile [online]. Chile: Naciones Unidas. Available from: https://repositorio.cepal.org/bitstream/handle/11362/40308/ S1600413_es.pdf

CORREA-RESTREPO, F., 2008. Tasa de descuento ambiental Gamma: una aplicación para Colombia. Lecturas de Economía, vol. 69 , no. 69 , pp. 141-162.

DE LA BARRERA, F., BACHMANN-VARGAS, P. and TIRONI, A., 2015. La investigación de servicios ecosistémicos en Chile: una revisión sistemática. Investigaciones Geográficas, no. 50, pp. 3-18. http://dx.doi.org/10.5354/0719-5370.2015.41171.

EDWARDS, G., 2016. Estimación de la tasa social de descuento a largo plazo en el marco de los sitemas nacionales de inversión. Aplicación al caso chileno. El Trimestre Economico, vol. 83, no. 329, pp. 99-125. http://dx.doi.org/10.20430/ete.v83i329.193.

FOOD AND AGRICULTURE ORGANIZATION OF THE UNITED NATIONS - FAO, 2017 [viewed 27 August 2018]. Water for sustainable food and agriculture a report produced for the $G 20$ presidency of germany [online]. Rome: FAO. Available from: http://www.fao.org/3/a-i7959e.pdf

FRAIRE-PACHECO, K., ARANCIBIA-AVILA, P., CONCHA, J., ECHEVERRÍA, F., SALAZAR, M.L., FIGUEROA, C., ESPINOZA, M., SEPÚLVEDA, J., JARA-ZAPATA, P., JELDRES-URRA, J. and VEGA-ROMÁN, E., 2017. A new report of Craspedacusta sowerbii (Lankester, 1880) in southern Chile. BioInvasions Records, vol. 6, no. 1, pp. 25-31. http://dx.doi. org/10.3391/bir.2017.6.1.05.

GONZÁLEZ-ACUÑA, D., BENAVENTE-CARMONA, C. and FIGUEROA-ROJAS, R., 2004. Avifauna de la Laguna Santa Elena, Región del Bío-Bío. Boletín Chileno de Ornitología, vol. 10, pp. 13-18.

GORDON, R. and DAHL, G.B., 2013. What do economists think about major public policy issues? Views among economists: professional consensus or point-counterpoint? The American Economic Review, vol. 103, no. 3, pp. 629-635. http://dx.doi. org/10.1257/aer.103.3.629.

HAUSMAN, J., 2012. Contingent valuation: from dubious to hopeless. The Journal of Economic Perspectives, vol. 26, no. 4, pp. 43-56. http://dx.doi.org/10.1257/jep.26.4.43. 
HENRI, J.-F. and JOURNEAULT, M., 2010. Eco-control: the influence of management control systems on environmental and economic performance. Accounting, Organizations and Society, vol. 35, no. 1, pp. 63-80. http://dx.doi.org/10.1016/j.aos.2009.02.001.

HIDALGO-FERNÁNDEZ,A. and HIDALGO FERNÁNDEZ, R., 2016. Lagunas de zóñar y del rincón (Córdoba, España). Aproximación a su valor de uso recreativo. Cuadernos Geográficos, vol. 55, no. 1, pp. 309-331.

JARAMILLO, A., BURKE, P. and BEADLE, D. (2005). Aves de Chile. Barcelona: Ingoprint S. A., 240 pp.

JONES, B. A., BERRENS, R. P., JENKINS-SMITH, H., SILVA, C., RIPBERGER, J., and CARLSON, D., 2018. Inclusive non-market valuation in Coupled Human and Natural Systems (CHANS): a motivating theory. Journal of Environmental Economics and Policy, vol. 8, no. 1, pp. 1-16. http://dx.doi.org/ $10.1080 / 21606544.2018 .1479315$.

LEE, J.F.J., SPRINGBORN, M., HANDY, S.L., QUINN, J.F. and SHILLING, F.M., 2010. Approach for economic valuation of environmental conditions and impacts. Prepared for Caltrans, $123 \mathrm{pp}$.

LIU, K.F.R., HSU, C.Y., YEH, K. and CHEN, C.W., 2011. Hierarchical analytic network process and its application in environmental impact evaluation. Civil Engineering and Environmental Systems, vol. 28, no. 1, pp. 1-18. http://dx.doi. org/10.1080/10286600903215078.

MALDONADO, J., 2015 [viewed 27 August 2018]. Gestión ambiental para un desarrollo humano sustentable [online]. Santiago: Universidad Miguel de Cervantes, pp. 77. Available from: http:// www.kas.de/wf/doc/kas_42154-1522-4-30.pdf?150730165427

NOBLE, B., 2004. Strategic environmental assessment quality assurance: evaluating and improving the consistency of judgments in assessment panels. Environmental Impact Assessment Review, vol. 24, no. 1, pp. 3-25. http://dx.doi.org/10.1016/S01959255(03)00118-5.
OBANDO-BASTIDAS, J., CASTELLANOS-SÁNCHEZ, M. and FRANCO-MONTENEGRO, A., 2016. Valoración económica del recurso natural agua del humedal Coroncoro de Villavicencio. Lámpsakos, vol. 16, no. 16, pp. 33-43. http://dx.doi. org/10.21501/21454086.1921.

ORGANISATION FOR ECONOMIC CO-OPERATION AND DEVELOPMENT - OECD, 2016 [viewed 27 August 2018]. OECD compendium of productivity indicators 2016 [online]. Paris: OECD Publishing. Available from: http://dx.doi.org/10.1787/ pdtvy-2016-en

RAHMAN, M.M., JIANG, Y. and IRVINE, K., 2018. Assessing wetland services for improved development decision-making: a case study of mangroves in coastal Bangladesh. Wetlands Ecology and Management, vol. 26, no. 4, pp. 563-580. http:// dx.doi.org/10.1007/s11273-018-9592-0.

REHNER, J., BAEZA, S.A. and BARTON, J.R., 2014. Chile's resource-based export boom and its outcomes: regional specialization, export stability, and economic growth. Geoforum, vol. 53, pp. 35-45. http://dx.doi.org/10.1016/j.geoforum.2014.06.007.

RESENDE, F.M., FERNANDES, G.W., ANDRADE, D.C. and NÉDER, H.D., 2017. Economic valuation of the ecosystem services provided by a protected area in the Brazilian Cerrado: application of the contingent valuation method. Brazilian Journal of Biology $=$ Revista Brasileira de Biologia, vol. 77, no. 4, pp. 762-773. http://dx.doi.org/10.1590/1519-6984.21215. PMid:28562788.

RIERA, P., GARCÍA, D., KRISTROM, B. and BRANNLUND, R., 2016. Manual de economía ambiental y de los recursos naturales. 3rd ed. Madrid: Ed. Paraninfo.

SAATY, T.L., 2008. Decision making with the analytic hierarchy process. International Journal of Services Sciences, vol. 1, no. 1, pp. 83-98. http://dx.doi.org/10.1504/IJSSCI.2008.017590.

TOLEDO, R., ENGLER, A. and AHUMADA, V., 2011. Evaluation of risk factors in agriculture : an application of the analytical hierarchical process (AHP) methodology. Chilean Journal of Agricultural Research, vol. 71, no. 1, pp. 114-121. http://dx.doi. org/10.4067/S0718-58392011000100014. 